\title{
Impact of Landscape Tree Stabilization System and Nursery Production Method on Anchorage and Growth
}

\author{
Edward F. Gilman, Chris Harchick, and Maria Paz
}

\begin{abstract}
The purpose of this study was to evaluate growth and anchorage one year after landscape planting of red maple (Acer rubrum L. 'Florida Flame') from both a field and container nursery that were stabilized with above- or belowground systems. Trunk diameter increased more for trees planted from containers with soilless substrate $(17 \mathrm{~mm})$ than trees with a soil root ball from a field nursery $(14 \mathrm{~mm})$; however, there was no impact of nursery production method on tree height. Trees secured with a guying system grew less in trunk diameter than trees secured with a belowground system, with a tall wood stake system, or the nonstaked control. Guyed trees were taller than trees secured with a root-ball stabilization system. More bending stress was required to winch trees transplanted from the field nursery than trees from containers immediately after releasing stakes one year after planting. There was no difference among stabilization systems in bending stress to winch to any trunk tilt angle, indicating similar anchorage across systems. Moreover, trees stabilized for one year required the same bending stress to winch as controls, indicating that stabilizing trees for one year with any of the systems tested did not reduce anchorage compared to non-stabilized trees.

Key Words. Acer rubrum; Lateral Stability; Nursery Production; Planting; Red Maple; Root Cross-Sectional Area; Staking; Transplanting; Trunk Tilt; Winching.
\end{abstract}

Trees are secured to the ground with a variety of stabilization systems (also referred to as staking systems) when planted into landscapes (Watson and Himelick 2013). Their performance varies in their ability to prevent overturning in windstorms measured immediately following planting (Ekstein 2007; Alvey et al. 2009). Staking trees can hinder development of trunk (Neel 1967; Harris et al. 1976) and root tissue (Stokes et al. 1995); for this reason, Leiser and Kemper (1968) suggested that landscape trees should be staked for short periods of time and no higher than two-thirds the height of the tree.

Appleton (2004) examined several aboveground and belowground systems, measuring trunk damage and trunk diameter change to estimate taper. There were considerable differences in trunk taper among systems for staked trees and slight trunk damage from the aboveground staking after one year. Another study examined trunk taper changes from stabilizing trees with one of three aboveground staking systems (Svihra et al. 1999). They and others (Neel 1967) found less taper on staked trees than on trees that were not staked, and increasing the rigidity of the staking system decreased trunk diameter growth and suppressed taper development. The influence on anchorage after the stabilization system was removed remains unclear.

Root architecture, tree size and age, and soil attributes influence stability of established trees (Stokes et al. 1995). Therefore, nursery production system could impact anchorage on recently planted landscape trees because of production system influence on root architecture. Many stability studies were conducted on trees planted from small propagation-sized $(5 \mathrm{~cm}$ diameter) containers used in reforestation. Some showed no difference in stability several years after planting liner stock from various container types (Robert and Lindgren 2006). Others showed planted trees were less stable than naturally regenerated trees due to a combination of less root cross-sectional area (CSA), poor root 
symmetry, and reduced number or diameter of straight roots (Lindstrom and Rune 1999).

Older trees planted from landscape nurseries have also been evaluated for stability. Trees transplanted from a field nursery were more stable in the landscape than comparably sized trees planted from $170 \mathrm{~L}$ (Gilman and Masters 2010) or $270 \mathrm{~L}$ (Gilman 2013) containers and required significantly more bending stress to tilt trunks to various angles. In addition to the greater root ball mass per unit of trunk diameter from a field nursery, several factors could explain reduced stability of trees planted from containers compared to transplanted, field-grown trees. In one of these studies, trees from $170 \mathrm{~L}$ containers had one-quarter the root CSA growing into landscape soil, one-third the root $\mathrm{CSA} / \mathrm{cm}^{2}$ of trunk CSA, one-half the number of roots, two-thirds the number of roots/ $\mathrm{cm}^{2}$ trunk CSA, and smaller diameter roots measured just outside the original root ball compared with field-grown trees (Gilman and Masters 2010).

Other than Alvey et al. (2009), there are few published studies comparing stability a year or more following planting once stakes are removed. The purpose of this study was to evaluate trunk and root growth and lateral stability or anchorage one year after planting trees from both a field and container nursery for several above- and belowground stabilization systems. An Acer rubrum cultivar ('Florida Flame') was chosen due to the popularity of the taxon in North American landscapes.

\section{MATERIALS AND METHODS}

\section{Trees}

Twenty Acer rubrum L. 'Florida Flame' trees in \#30 (111 L) containers with soilless substrate were hand-selected from a container nursery to be similar in trunk diameter $[57 \mathrm{~mm}$ trunk diameter, SD (standard deviation) 3.7] with straight trunks. Tree trunks were clear of branches in the lower $1.3 \mathrm{~m}$. Twenty trees of comparable size (55 $\mathrm{mm}$ trunk diameter, SD 2.9), were hand-selected from a field nursery. All 40 trees were planted as liners from 3.7 L containers approximately 24 months earlier. Field-grown trees were dug five weeks prior to planting from an exceptionally welldrained Orlando, Florida, U.S., fine sand field soil at Marshall Tree Farm (Moriston, Florida, U.S.) with a mechanical tree spade. Trees were placed back into the same hole in natural burlap in a flatbottomed, $61 \mathrm{~cm}$ top diameter wire basket and cinched tight with string. Some new roots were growing through burlap when trees were picked up from the nursery a day prior to study initiation.

Trees were planted $2.2 \mathrm{~m}$ apart in two rows spaced $3.6 \mathrm{~m}$ apart during the week of 23 March 2009 into flat-bottomed holes as deep as the root ball. Holes were square with $1.3 \mathrm{~m}$ long vertical sides. The top of the root ball and the root collar were positioned even with the landscape soil. Root ball edge was placed at the same distance $(30 \mathrm{~cm})$ from the north edge of each hole. Site soil was added as backfill about half way up the root ball and was uniformly packed by the same person walking on the backfill with 20 steps. The remaining backfill soil was added to the top edge of the root ball and again lightly packed by walking, with 20 steps around the tree.

Irrigation was applied $(20 \mathrm{~L})$ to the root ball surface once daily for the duration of the study, using three spray emitters with an identical volume. Fertilizer ( $200 \mathrm{~g}, 16 \mathrm{~N}: 4 \mathrm{P}_{2} \mathrm{O}_{5}: 8 \mathrm{~K}_{2} \mathrm{O}$ ) was applied in June 2009 to the soil surface of the planting hole. Mulch was not added to the site; instead, three applications of glyphosate (Roundup ${ }^{\circ}$ ) were applied during the growing season to a $1.3 \mathrm{~m}$ wide strip centered on the trunk down each row. The plot was an open, flat field (Millhopper fine sand: loamy, siliceous, hyperthermic Grossarenic Paleudults) with 25 to $30 \mathrm{~m}$ tall trees several hundred $\mathrm{m}$ away at University of Florida in Gainesville Florida in USDA (1990) hardiness zone 8b.

\section{Stabilization System Installation}

Four stabilization systems were tested, including a staking system, a guying system, a root-ball anchoring system, and a non-stabilized control. The staking system (LP) used lodgepole pine wooden poles $2.5 \mathrm{~m}$ long with a $6 \mathrm{~cm}$ diameter driven vertically $0.9 \mathrm{~m}$ deep, $12 \mathrm{~cm}$ outside the edge of the root ball. Two stakes were used per tree, one on the east and one on the west side. Deep Root Arbortie ${ }^{\varpi}$ (Deep Root Partners L.P., San Francisco, California, U.S.), $18 \mathrm{~mm}$ wide strapping was secured to the top of a stake, strung horizontally to the trunk $1.4 \mathrm{~m}$ from the ground, wrapped half way around trunk, and again secured to the same 
stake. A second Arbortie was secured to the trunk and to the other stake in an identical manner.

The guying system (GS) used was Arbortie strapping tied to short stakes $(0.62 \mathrm{~m}$ long, $38 \mathrm{~mm} \times$ $38 \mathrm{~mm}$, non-treated dimensional lumber) driven $0.46 \mathrm{~m}$ into ground. Lumber was installed on a 30-degree angle to vertical so that bottom of stake was closer to the trunk than the top. Strapping was tied to the trunk with a non-slip knot just above a branch cluster as close to $1.4 \mathrm{~m}$ from ground as possible. The other end of the strapping was tied to the short stakes and secured with a screw to prevent slippage. Three stakes were positioned 120 degrees apart with two on the south side and one to north. Previous research showed that winching direction had no impact on bending stress required to cause tree or system failure (Ekstein 2007).

The root-ball stabilization system (TT) was the Terra Toggle ${ }^{\mathrm{Tm}}$ (Accuplastics Inc., Brooksville, Florida, U.S.). Two $3.8 \mathrm{~cm} \times 8.9 \mathrm{~cm}(2 \times 4$ nominally dimensional lumber) untreated pine boards were placed on the root ball parallel to one another at $5 \mathrm{~cm}$ from and tangent to the trunk on opposite sides. Lumber was cut to the same length as the width of the root ball. One Terra Toggle Earth Anchor was driven $1.2 \mathrm{~m}$ into the ground at each end of each piece of lumber at approximately a ten degree angle from vertical away from the tree using a water jet driving tool provided by the manufacturer. Earth Anchors were tied to low-stretch $25 \mathrm{~mm}$ wide plastic strapping that secured the lumber tightly to the top of the ball. Two straps were connected with a metal buckle on top of the lumber, and slack was removed with a strapping tool supplied by the manufacturer. All systems were illustrated in Ekstein (2007).

\section{Winching Trees}

All trees were winched due north on 6-12 April 2010 , with a cable and electric winch mounted on a tractor to evaluate lateral stability (Gilman and Masters 2010). An inclinometer (model N4; Rieker Inc., Aston, Pennsylvania, U.S.) was mounted to a fabricated steel plate $(5.1 \mathrm{~cm} \times 7.6 \mathrm{~cm})$. The plate was strapped to the trunk base $15 \mathrm{~cm}$ from the soil surface, which was just above the swollen root collar. A $3,629 \mathrm{~kg}$ capacity load cell (SSM-AF-8000; Interface Inc., Scottsdale, Arizona, U.S.) was placed in line with a pulling cable attached to the trunk $1.7 \mathrm{~m}$ above ground.
Trees were winched so the cable remained parallel to ground. The cable was pulled at $2 \mathrm{~cm} \bullet$ second $^{-1}$ until the trunk base tilted five degrees, and then the cable was let slack. The trunk angle was recorded during winching. One minute later, the tree was pulled to ten degrees, let slack, and the trunk tilt angle was recorded as the rest angle after letting the cable go slack. Data from load cell and inclinometer was collected at $2 \mathrm{~Hz}$ by Data Acquisition System (National Instruments Corporation, Austin, Texas, U.S.). Data were displayed in real time, during pulling tests, on a laptop running LabView software (v: 7.0; National Instruments, Austin, Texas, U.S.). Trunk bending stress at position of inclinometer at one, five, and ten degrees was calculated according to Equation 1 (Gilman and Masters 2010).

$$
\sigma=\frac{F \cdot d \cdot R}{\frac{\pi}{4} \cdot R^{4}}
$$

where $\quad \sigma=$ bending stress

$\mathrm{F}=$ pulling force

$\mathrm{d}=$ distance from pulling point to inclinometer

$\mathrm{R}=$ trunk radius (calculated as halving di-

ameter measured with a diameter tape at inclinometer)

\section{Growth Data Collection}

The initial trunk diameter was measured $15 \mathrm{~cm}$ from the ground on 30 March 2009. Trunk diameter and tree height were measured 30 September 2009. Root balls were dug from the ground immediately after winching on 14 April 2010, and all roots cut at $5 \mathrm{~cm}$ beyond the edge of the original circular root ball. The diameter of the trunk and all roots greater than 2.5 $\mathrm{mm}$ diameter in the top $25 \mathrm{~cm}$ of the soil profile were measured at the cut surface. Measurements were independently collected in four 90 -degree quadrants: leeward (north), windward (south), east, and west.

\section{Experimental Design and Data Analysis}

The design was a randomized complete block in five blocks of eight trees. Each stabilization system (four systems) was installed on one tree of each nursery production method (two methods, container and field grown) for a total of $4 \times 2=8$ trees per block. All trees in a block were pulled on the same day. Data were analyzed using SAS as a randomized complete block design with nursery produc- 
tion method (container or field) and stabilization systems as fixed effects. When the treatment main effect was significant, multiple comparisons were made using Duncan's multiple range test $(P<0.05)$.

\section{RESULTS AND DISCUSSION}

There was no impact of production system on tree height measured in the first year after landscape planting (Table 1). Trunk diameter, in the first year after landscape installation, increased 3 $\mathrm{mm}$ more $(P=0.0004, \mathrm{n}=20)$ for trees planted from containers $(17 \mathrm{~mm})$ than trees from the field nursery (14 mm). Harris and Gilman (1993) also found a slight increase in trunk diameter growth in the first year after planting containers compared to recently dug field-grown trees. This was attributed to the sudden and recent loss of a portion of the root system on trees dug from the field that were not root pruned prior to digging in the nursery. Subsequent study showed that hardened-off field-grown trees-those dug and held in the nursery under intense irrigation management for several months prior to planting into the landscape-were capable of establishing faster than those planted from containers. Greater resilience following planting of hardened-off field-grown nursery stock was due to the root regeneration that occurred while trees were held in the nursery prior to planting into the landscape combined with the drying effect of soilless substrate typical of container nurseries in the moist climate of the southeastern United States (Gilman 2001; Gilman et al. 2010). Results in the current study might be different in other regions where soil is a component of container substrate or if trees were not held (hardenedoff) for five weeks following digging and prior to planting. Despite differences among nursery production systems in establishment rate found in this and the cited studies, trees from any production system can be established by controlling soil moisture with irrigation management after planting (Marler and Davies 1987; Beeson and Gilman 1992; Dana and Blessing 1994).

Immediately after releasing stakes from the tree one year after landscape planting, more bending stress was required to winch trees transplanted from the field nursery to one and five degrees than trees planted from containers (Table 2 ); however, there was no difference between the two nursery production methods to winch to ten degrees $\left(70,585 \mathrm{kN} / \mathrm{m}^{2}\right)$. Rest angle immediately following cable release at ten degrees tilt on trees planted from containers (3.7 degrees) was more than twice that of trees transplanted from the field nursery (1.7; $P=0.002$ ), indicating greater stability of Acer rubrum trees planted from the field nursery. Quercus virginiana Mill., with a 12 to $18 \mathrm{~cm}$ trunk diameter from a field nursery, were also found to be better anchored to landscape soil in the first three years after planting than those from containers (Gilman and Masters 2010; Gilman 2013). This was attributed to a combination of four times the total root CSA extending into landscape soil, twice the number of roots, larger diameter roots all measured just outside the original root ball, and greater mass within the planted root ball compared to container-grown trees.

Others also found that bending moment required to tilt trunks was influenced by nursery produc-

Table 1. Total root cross-sectional area (CSA) measured $5 \mathrm{~cm}$ beyond root ball edge in top $25 \mathrm{~cm}$ soil profile one year after planting Acer rubrum into landscape soil from container or field nursery.

\begin{tabular}{lll}
\hline Production method & Total root CSA $\left(\mathrm{mm}^{2}\right)$ & Tree height $(\mathrm{m})$ \\
\hline Container & $1,391 \mathrm{~b}^{2}$ & $4.42 \mathrm{a}$ \\
Field & $1,862 \mathrm{a}$ & $4.58 \mathrm{a}$ \\
\hline
\end{tabular}

${ }^{\mathrm{z}}$ Means within a column with different letter are statistically different at $P<0.05 ; \mathrm{n}=20$, averaged across staking system due to insignificant interaction.

Table 2. Bending stress required to winch Acer rubrum, planted from container or field nursery, following removal of stabilization systems one year after planting.

\begin{tabular}{lll}
\hline Production method & $\begin{array}{l}\text { Bending stress to one } \\
\text { degree trunk tilt }\left(\mathrm{kN} / \mathrm{m}^{2}\right)\end{array}$ & $\begin{array}{l}\text { Bending stress to five } \\
\text { degrees trunk tilt }\left(\mathrm{kN} / \mathrm{m}^{2}\right)\end{array}$ \\
\hline Container & $8,972 \mathrm{~b}^{\mathrm{z}}$ & $29,210 \mathrm{~b}$ \\
Field & $10,554 \mathrm{a}$ & $36,316 \mathrm{a}$ \\
\hline
\end{tabular}

${ }^{\mathrm{z}}$ Means within a column with different letter are statistically different at $P<0.05 ; \mathrm{n}=20$, averaged across stabilization system due to insignificant interaction. 
tion method for small seedlings planted as part of reforestation (Lindstrum and Rune 1999). Unlike these cited studies, Acer rubrum in the current study had the same number of roots growing into landscape soil from both production systems. However, Acer rubrum in the current study mimicked the response seen in Quercus virginiana (Gilman and Masters 2010) with smaller diameter roots and less total root CSA on trees planted from containers than those transplanted from the field nursery (Table 1). Increased root diameter and CSA on Acer rubrum trees from the field nursery likely accounted for improved anchorage compared to those planted from containers.

Trunk diameter growth was impacted by tree stabilization system (Table 3 ). In contrast to Appleton (2004), trees secured with the GS grew slightly less in trunk diameter than trees secured with the TT and LP systems and the non-staked control; trees secured with TT and LP grew similar in trunk diameter to the controls. Trees secured with LP and GS were taller than non-stabilized control trees. Guyed trees were also taller than TT trees. The GS secured the trunk in a rigid manner providing for the least amount of movement in windy weather (observed, not measured). Rigidly secured trees had slow trunk diameter growth and/or increased tree height on young Liquidambar styraciflua L. (Leiser et al. 1972), Myoporum R.Br. (Harris and Hamilton 1969), and Pyrus calleryana Decne. trees (Shvira et al. 1999). Although aboveground growth differences can be statistically significant (Labrosse et al. 2011), differences are often small (Appleton 2004) and may not have practical significance in every application. Perhaps the most negative effect of stabilization systems is retaining the tying mechanism on the trunk, which can result in trunk girdling and cambium death (Labrosse et al. 2011).
Alvey et al. (2009) found that the GS was more effective at resisting failure than the belowground stabilization system; however, the vertical components in that belowground system were only $61 \mathrm{~cm}$ deep-a deeper $(123 \mathrm{~cm})$ system was found by Ekstein (2007) to be as effective as the GS. There was no difference among stabilization systems in bending stress to winch to any trunk tilt angle immediately after release of stakes one year after planting (data not shown), indicating similar anchorage across systems. Moreover, trees stabilized for one year required the same bending stress to winch to one, five, or ten degrees tilt as trees never stabilized (i.e., controls), indicating that stabilizing Acer rubrum trees for one year with any of the systems tested did not reduce anchorage compared to non-stabilized trees. Alvey et al. (2009) found similar results on trees released from similar stabilization systems seven months after planting.

There were no differences in root attributes among treatments with one exception: the mean CSA of roots greater than $2.5 \mathrm{~mm}$ diameter on trees from the field nursery stabilized with the GS $\left(31 \mathrm{~mm}^{2}\right)$ was greater than for all stabilized container trees and control field-grown trees (Table 4). The enhanced rigidity of the GS may have stabilized the freshly-dug root balls to take full advantage of the inherently larger root growth capacity of field-grown trees compared to trees planted from containers (Gilman and Beeson 1996). Enhanced rigidity could have allowed roots to become larger because tender roots would not have been broken during stormy weather. Trees planted from containers may not have responded to the rigidity of this system due to their smaller root growth capacity. There is direct evidence of smaller root growth capacity of Acer planted from containers than those transplanted from the field in the current study (Table 3).

Table 3. Effect of stabilization system on trunk diameter increase and tree height of Acer rubrum planted March 2009.

\begin{tabular}{lll}
\hline Tree stabilization & Trunk diameter increase April & $\begin{array}{l}\text { Tree height Sept. } \\
2009(\mathrm{~m})\end{array}$ \\
system & 2009 to April 2010 (mm) & $4.3 \mathrm{c}$ \\
None (control) & $15.7 \mathrm{a}^{\mathrm{z}}$ & $4.5 \mathrm{bc}$ \\
Terra Toggle (TT) & $16.9 \mathrm{a}$ & $4.7 \mathrm{ab}$ \\
Lodgepole (LP) & $14.1 \mathrm{a}$ & $4.9 \mathrm{a}$ \\
Guying (GS) & $11.4 \mathrm{~b}$ & $\mathrm{a}$ \\
\hline
\end{tabular}

${ }^{\mathrm{z}}$ Means within columns with different letter are statistically different at $P=0.0002 ; \mathrm{n}=10$, averaged across tree production method due to insignificant interaction. 
Table 4. Mean root cross-sectional area (CSA) one year after planting Acer rubrum into landscape soil from container or field nursery.

\begin{tabular}{lll}
\hline Production method & Staking system & Mean root CSA $\left(\mathrm{mm}^{2}\right)$ \\
\hline Container & None (control) & $17 \mathrm{bc}^{\mathrm{z}}$ \\
& Guying & $14 \mathrm{c}$ \\
& Lodgepole & $18 \mathrm{bc}$ \\
& Terra Toggle & $16 \mathrm{bc}$ \\
Field & None (control) & $31 \mathrm{bc}$ \\
& Guying & $23 \mathrm{abc}$ \\
& Lodgepole & $24 \mathrm{ab}$ \\
\hline
\end{tabular}

${ }^{\mathrm{z}}$ Means within a column with different letter are statistically different at $P<0.05 ; \mathrm{n}=5$. CSA is mean of all roots greater than $2.5 \mathrm{~mm}$ diameter measured $5 \mathrm{~cm}$ beyond root ball edge in top $25 \mathrm{~cm}$ soil profile.

\section{CONCLUSIONS}

The guying tree stabilization system resulted in the tallest Acer rubrum trees with the smallest trunk diameter one year after landscape planting. However, stabilizing trees for one year after planting by any system tested resulted in no reduction in anchorage compared to non-stabilized controls once the tree was released from the systems. Trees planted with a soilless root ball from containers grew about the same in the first year after planting as those with a mineral soil root ball from a field nursery. Trees planted from containers were less well-anchored than those transplanted from a field nursery. This likely was the result of smaller diameter roots and less total root CSA on trees planted from containers than those transplanted from the field nursery.

Acknowledgment. Thank you to the DuPont Corporation for partial funding.

\section{LITERATURE CITED}

Alvey, A, P.E. Wiseman, and B. Kane. 2009. Efficacy of conventional tree stabilization systems and their effect on short-term tree development. Arboriculture \& Urban Forestry 35:157-164.

Appleton, B.L. 2004. Tree stabilization at installation. Southern Nurseryman Association Annual Research Conference Proceedings 49:437-440.

Beeson, R.C., and E.F. Gilman. 1992. Water stress and osmotic adjustment during post-digging acclimatization of Quercus virginiana produced in fabric containers. Journal of Environmental Horticulture 10:208-214.

Dana, M.N., and S.C. Blessing. 1994. Post-transplant root growth and water relations of Thuja occidentalis from field and containers. In: G.W. Watson and D. Neely (Eds.). The Landscape Below Ground. Proceedings of International Workshop on Tree Root Development in Urban Soils. International Society of Arboriculture, Savoy, Illinois, U.S.

Eckstein, R. 2007. Evaluation of landscape tree stabilization systems in simulated wind. Master's thesis. University of Florida, Gainesville, Florida, U.S.
Gilman, E.F. 2001. Effect of nursery production method, irrigation, and inoculation with mycorrhizae-forming fungi on establishment of Quercus virginiana. Journal of Arboriculture 27:30-39.

Gilman, E.F., and R.C. Beeson, Jr. 1996. Nursery production method affects root growth. Journal of Environmental Horticulture 14:88-91.

Gilman, E.F., and F. Masters. 2010. Effect of tree size, root pruning, and production method on root growth and lateral stability of Quercus virginiana. Arboriculture \& Urban Forestry 36:281-291.

Gilman, E.F., C. Harchick, and M. Paz. 2010. Effect of tree size, root pruning and production method on establishment of Quercus virginiana. Arboriculture \& Urban Forestry 36:183-190.

Gilman, E.F. 2013. Anchorage influence by production method and root pruning. Arboriculture \& Urban Forestry 39:1-5.

Harris, J.R., and E.F. Gilman. 1993. Production method affects growth and post-transplant establishment of 'East Palatka' holly. Journal of American Society Horticulture Science 118:194-200.

Harris, R., A.T. Leiser, and W.B. Davis. 1976. Staking landscape trees. University of California Agricultural Extension leaflet 2576.

Harris, R.W., and W.D. Hamilton 1969. Staking and pruning young Myoporum laetum trees. Journal American Society for Horticultural Science 94:359-361.

Labrosse, K.J., R.C. Corry, and Y. Zheng. 2011. Effects of tree stabilization systems on tree health and implications on planting specifications. Arboriculture \& Urban Forestry 37:219-225.

Leiser, A.T., and J.D. Kemper. 1968. A theoretical analysis of a critical height of staking landscape trees. American Society for Horticultural Science 92:713-720.

Leiser, A.T., R. Harris, P. Neel, D. Long, N. Stice, and R. Maire. 1972. Staking and pruning influence trunk development of young trees. Journal of American Society Horticultural Science 97:498-503.

Lindstrom, A., and G. Rune. 1999. Root deformation in plantations on container-grown Scots pine trees: Effects on root growth, tree stability, and stem straightness. Plant and Soil 217:29-37.

Marler, T.E., and F.S. Davies. 1987. Growth of bare-root and container grown 'Hamlin' orange trees in the field. Proceedings Florida State Horticulture Society 100:89-93.

Neel, P.L. 1967. Factors influencing trunk development of landscape trees. Proceedings of the International Shade Tree Conference 43:293-303.

Robert, J.A., and B.S. Lindgren. 2006. Relationships between root form and growth, stability, and mortality in planted versus naturally regenerated lodgepole pine in north-central British Columbia. Canadian Journal of Forest Research 36:2642-2653. 
Stokes, A., A.H. Fitter, and M.P. Coutts. 1995. Responses of young trees to wind and shading: Effects on root architecture. Journal of Experimental Botany 46:1139-1146.

Svihra, P., D. Burger, and D. Ellis. 1999. Effects of three trunk support systems on growth of young Pyrus calleryana trees. Journal of Arboriculture 25:319-324.

Watson, G.W., and G. Himelick. 2013. The Practical Science of Planting Trees. International Society of Arboriculture, Champaign, Illinois, U.S. 250 pp.

\section{Edward F. Gilman (corresponding author) \\ University of Florida \\ Environmental Horticulture \\ 1533 Fifield Hall \\ Gainesville, Florida 32611, U.S. \\ egilman@ufl.edu}

Chris Harchick

University of Florida

Environmental Horticulture

1533 Fifield Hall

Gainesville, Florida 32611, U.S.

Maria Paz

University of Florida

Environmental Horticulture

1533 Fifield Hall

Gainesville, Florida 32611, U.S.

Résumé. L'objectif de cette étude était d'évaluer la croissance et l'ancrage au sol, un an après leur plantation sur un site paysagé, d'érables rouges (Acer rubrum L. 'Florida Flame') produits en pleine terre ou en contenants dans une pépinière, qui avaient été stabilisés avec des systèmes souterrain ou hors-sol. Le diamètre du tronc a davantage augmenté chez les arbres plantés provenant de contenants avec un substrat sans terre $(17 \mathrm{~mm})$ que chez les arbres en motte extraits du sol de la pépinière $(14 \mathrm{~mm})$; cependant, quelque soit la méthode de production en pépinière, il n'y avait pas d'impact sur la hauteur des arbres. Les arbres stabilisés avec un système de haubanage au sol présentaient une moindre croissance du diamètre $\mathrm{du}$ tronc que les arbres stabilisés avec un système souterrain, avec un long tuteur en bois ou que les arbres témoins sans aucun tuteur. Les arbres haubanés au sol étaient plus grands que les arbres stabilisés avec un système de stabilisation souterrain. Une contrainte de flexion plus élevée a été nécessaire pour treuiller les arbres cultivés en pleine terre en pépinière que les arbres produits en contenants immédiatement après avoir retiré les tuteurs un an après la plantation. Il n'y avait pas de différence entre les systèmes de stabilisation quant à la contrainte de flexion requise pour le treuillage quelque soit l'angle d'inclinaison du tronc, ce qui indique un ancrage similaire selon les différents systèmes. De plus, les arbres stabilisés pendant un an requéraient la même contrainte de flexion au treuillage que les arbres témoins, ce qui indique que la stabilisation des arbres après une année avec l'un ou l'autre des systèmes testés ne réduisait pas l'ancrage par rapport aux arbres non stabilisés.

Zusammenfassung. Die Absicht dieser Studie lag in der Bewertung von Wachstum und Verankerung von Rotahornen (Acer rubrum L. 'Florida Flame') am Ende eines Jahr nach der Verpflanzung sowohl bei Freiland-, wie auch Container-Bäumen, die mit ober- oder unterirdischen Systemen stabilisiert wurden. Der Stammdurchmesser bei Bäumen aus Containern mit bodenfreiem
Substrat nahm mehr zu $(17 \mathrm{~mm})$ als bei Bäumen mit einem erdigen Wurzelballen aus dem Freiland $(14 \mathrm{~mm})$. Dennoch bestand kein Einfluss von der Baumschulproduktion auf die Baumhöhe. Bäume, die mit einem oberirdischen Abspannungs-Sicherungssystem stabilisiert wurden, wuchsen weniger im Stammdurchmesser als Bäume, die mit einem unterirdischen System, mit einer langen Holzstange gesichert wurden oder wie die nicht gestabten Kontrollbäume. Abgespannte Bäume waren größer als Bäumen mit einem Wurzelballen-Sicherungssystem. Um die aus dem Feld verpflanzten Bäume zu ernten, wurde mehr Biegebelastung ausgeübt als bei Bäumen, die aus Containern stammen, sofort nach der Entfernung der Stangen ein Jahr nach der Pflanzung. Es gab keine Unterschiede unter den Stabilisierungssystemen bei der Biegebelastung, um den Stamm in jeden Winkel zu biegen, was zeigt, dass die Systeme sich ähneln. Mehr noch: Bäume, die für ein Jahr stabilisiert wurden, erforderten die gleiche Biegebelastung wie die Kontrollbäume, was bedeutet, dass das Stabilisieren von Bäumen für ein Jahr mit irgendeinem System nicht im Vergleich zur Kontrolle die Verankerungsleistung reduziert.

Resumen. El propósito de este estudio fue evaluar el crecimiento y el anclaje un año después de la plantación de árboles de arce rojo (Acer rubrum L. 'Florida Flame'), procedentes del terreno y de contenedores de vivero que fueron estabilizados con sistemas encima y abajo del suelo. Los diámetros del tronco incrementaron más en los árboles de contenedores plantados con sustrato sin suelo (17 $\mathrm{mm})$ que los árboles con una bola de un vivero (14 mm); sin embargo, no hubo impacto en la altura del árbol con relación al método de producción. Los árboles que se aseguraron con un sistema de tensores crecieron menos en diámetro del tronco que los que se aseguraron con un sistema de tutoreo de madera, o el control no estacado. Los árboles con tensores fueron más altos que los árboles que se aseguran con un sistema de estabilización del cepellón. Se requirió más esfuerzo de flexión para vencer los árboles trasplantados de vivero que los árboles de los envases, inmediatamente después de la liberación de las estacas un año después de la plantación. No hubo diferencias entre los sistemas de estabilización en el esfuerzo de flexión en cualquier ángulo de inclinación del tronco, lo que indica anclaje similares en los sistemas. Por otra parte, los árboles estabilizados por un año requirieron el mismo esfuerzo de flexión que los controles, lo que indica que la estabilización de los árboles durante un año con cualquiera de los sistemas probados no redujo el anclaje en comparación con los árboles no estabilizados. 